\title{
The Tax Disadvantage Of Ordinary Income: An Event Study On The Legislative Process Of JGTRRA
}

Mingjun Zhou, Ph.D., DePaul University, USA

\begin{abstract}
The Jobs Growth and Tax Relief Reconciliation Act of 2003 (JGTRRA), signed into law by President George W. Bush, was a significant legislation in recent tax history. As the tax rates on capital gains and dividends are reduced to a historical low of 15\%, U.S. stock prices have increased and the cost of equity capital declined after its passage. In contrast to the dividends and capital gains that receive preferential tax rates under JGTRRA, yields from U.S. Treasury bill remain tax-disadvantaged as ordinary income at a top marginal rate of 35\%. Using an event study approach based on two years of Treasury yield observations, the author examines Treasury yield reactions to major legislative events surrounding the passage of JGTRRA. The result suggests that a tax policy intentionally favoring dividends and capital gains over ordinary income may unintentionally push up yields in the Treasury bill market, thereby affecting the cost of government borrowing.
\end{abstract}

Keywords: Jobs Growth and Tax Relief Reconciliation Act; JGTRRA 2003; Treasury Yield Reactions

\section{INTRODUCTION}

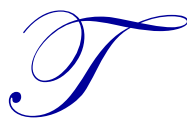

he Jobs Growth and Tax Relief Act of 2003 (JGTRRA) reduced the top marginal tax rate for individuals on qualified dividend income from 38.6 to 15 percent and that on net capital gains from 20 to 15 percent. Following the passage of JGTRRA, several empirical studies have suggested that individual investors favored stocks with large dividends and/or capital gains. As a result, stock prices increased and the cost of equity capital declined. (i.e., Dhaliwal et al. 2007; Auerbach and Hassett 2007; and Lightner et al. 2008). Empirical tax research on JGTRRA so far has supported the idea that taxes on individual shareholders affect the pricing of stocks.

On the other hand, how JGTRRA affects the debt market has not yet been widely examined. Following Guenther (1994), the author uses U.S. Treasury bill market as the setting to investigate the impact of a major tax cut on government debt securities. Treasury bills are U.S government obligations with maturities under one year, issued at a discount and without coupons. The yield from a Treasury bill realized at sale or upon maturity is taxed under the Internal Revenue Code as ordinary income. In contrast to the favorable tax rates on dividends and capital gains, JGTRRA leaves the top marginal tax rate on ordinary income at 35 percent. This differential tax treatment between ordinary income and capital gains/dividends has been the focus of debates on tax policy and tax reform. For example, the higher tax rate on ordinary income sparks the editorial Mr. Warren Buffet sent to the New York Times (August 14, 2011), arguing that he should not be paying a lower tax rate than his secretary's ordinary income, and law makers should stop "coddling the super rich" who receive large tax-advantaged income such as dividends and capital gains.

In this paper, the author studies the Treasury market reaction to the major legislative events surrounding JGTRRA. This paper contributes to existing research by documenting the upward pressure on U.S. Treasury yields to a capital gains and dividend tax cut. Tax policy that intentionally favors dividends and capital gains over interest income may affect yields in the Treasury bill market, thus affecting the cost of government borrowing. 


\section{INDIVIDUAL TAXES AND THE PRICING OF TREASURY BILLS}

As noted earlier, there is limited research on the effect of individual tax in the government securities after major tax legislations. Guenther (1994) investigates the Treasury yield spread across year-end in 1981 and 1986 and find that the yields appear to be affected by the implementation of the Economic Recovery Tax Act of 1981 (ERTA) and the Tax Reform Act of 1986 (TRA86). Although the available Federal Reserve Statistics does not indicate individual taxable investors to have a major holding in the overall Treasury securities market, the results in Guenther (1994) do suggest that taxable investors and their money managers influence the dynamics in the short-term Treasury bill market with their tax considerations.

Novack (2005) analyzed the extent to which U.S. Treasury yields might be impacted by a change in the capital gain tax on stocks. He reports that Treasury bill yields increased on the day that Congress announced the 1997 reduction in the tax rate on long-term capital gains (May 2, 1997) and again on the day that the tax cut became effective (May 7, 1997).

In this study, the author uses the setting of tax-rate changes provided by JGTRRA to investigate whether individual taxes on equity returns may influence the pricing dynamics in the bond market. The author documented an association between Treasury bill yields and changes in the tax rates on capital gains and dividend income. The author tried to find out whether Treasury bill yields increased significantly on the days surrounding the key legislative events favoring the passage of JGTRRA.

To answer this research question, the author developed a regression model based on Miller (1977). Because Treasury bills are usually considered as the "risk-free" expected return, equity investors expect their return $(R)$ to be the Treasury yield $(r)$ plus an equity risk premium $(r p m)$, and $R$ is further consisted of capital gains $(g)$ and dividends $(d)$ :

$R=g+d=r+r p m$

From Eq. (1),

$r=g-r p m+d$

The author then follows Mankiw and Poterba (1996)'s assumption that the equity risk premium could be constant in a regression equation and thus disappears in a first difference model. Therefore, the relationship between $r, g$ and $d$ can be modeled using a difference-in-difference regression design ${ }^{1}$.

$\Delta\left(1-t_{o}\right) r=\Delta\left(1-t_{g}\right) g+\Delta\left(1-t_{d}\right) d$

$t_{o}=$ the tax rate on ordinary income (e.g., interest income)

$r=$ the yield of an investment that is taxed as ordinary income

$t_{g}=$ the tax rate on capital gains

$g=$ the capital gain yield on an equity investment

$t_{d}=$ the tax rate on dividends

$d=$ the dividend yield on an equity investment

The partial derivatives for Eq. (3) can be described as:

$$
\frac{\partial \Delta r}{\partial \Delta t_{d}}=-\frac{-d}{1-t_{o}}
$$

\footnotetext{
${ }^{1}$ The use of a first difference model also follows the practice in Campbell and Shiller (1991) because the level of Treasury bill yields might not be a stationary process and thus could produce upwardly biased t-statistics in regression coefficient estimates.
} 
and:

$$
\frac{\partial \Delta r}{\partial \Delta t_{g}}=-\frac{-g}{1-t_{o}}
$$

Both Eq. (4) and Eq. (5) suggest that any tax cut in the dividend or capital gains rate can be associated with an increase in the Treasury bill yields when investors expect returns from capital gains and dividends $(\mathrm{d}>0$ and $\mathrm{g}>0)$. In other words, individual investors may rebalance their portfolios from the Treasury market to stocks when expecting that their returns from stocks may be more tax-advantaged following a reduction in the tax rates on dividends and capital gains. This would push down Treasury prices and drive up yields. This equilibrium and the intuition of behind prediction could be found in Miller (1977): “...If, therefore, the personal tax on income from common stocks is less than that on income from bonds, then the before-tax return on taxable bonds has to be high enough, other things equal, to offset this tax-handicap."

\section{Empirical Testing}

Sample and Measurement of Variables

The daily Treasury bill yield and maturity data in this study are drawn from the GovPX historical database. GovPX is set up by all the primary dealers and major interdealer brokers serving the U.S. Treasury market. GovPX supplies transaction-based daily U.S. Treasury securities information and thus provides us with an accurate measure of market clearing prices. The author used the daily average of the actual bid and asks quotes for each Treasury bill issue that are reported by GovPX in discount yield based on a 360-day year. Each of the daily average bid/ask discount yield pairs is converted to bid/ask prices according to Roll (1970) and Guenther (1994):

$$
P_{n, t}=100-(n / 360) Y_{n, t}^{\prime}
$$

$P_{n, t}$ is the current price of a $\$ 100$ (at maturity) bill that matures in $n$ days as of day $t . Y_{n, t}^{\prime}$ is the actual discount yield provided by GovPX in percentage points based on a 360-day year. The average price of each bid/ask pair $\left(P_{n, t}^{*}\right)$ is used to find a continuously compounded annualized (365-day year) yield-to-maturity $\left(Y_{t}\right)$ :

$$
Y_{t}=(365 / n) \ln \left(100 / P_{n, t}^{*}\right)
$$

The calculated annualized yield is then converted into basis points. The author selected Treasury bills that are auctioned initially by the Treasury with maturities of 13 and 26 weeks as they are the most actively traded. Each Treasury bill issue is identified by its CUSIP number in the GovPX database.

The author then adopted an event study approach examining Treasury bills yields on key legislative events surrounding JGTRRA using the following regression:

$$
\Delta Y_{i, t(n)}=\gamma_{0(n)}+\gamma_{(n)} D_{(n)}+k_{(n)} \text { Control }+\varepsilon_{i, t(n)}
$$

In the regression model (Eq. 8), the dependent variable is the daily change in the yield-to-maturity of Treasury bill $i$ measured at day $t . D_{(n)}$ is a dummy that is equal to one if measured on any day within the three-day event window $n$ and zero otherwise. The author ran ten regressions to estimate the ten coefficients $\gamma_{(n)}$ for each of the ten event windows. Each coefficient represents the average "abnormal" change in Treasury bill yield during event window $n$. The estimation period used to determine expected changes in Treasury bill yields starts on the first trading day in June 2002 and ends on the last trading day in May 2004. 
The author used generalized least squares to estimate our regression model. Each issue of Treasury bills of a given maturity forms one cluster and used clustered standard error estimates to adjust for the correlation in the error terms for the same Treasury bill through time, ${ }^{2}$ which are shown to be unbiased in the regression analysis using panel data sets by Petersen (2009). For the control variables, the first two are the term spread and the default spread. The term spread (TERM) is defined as the spread between the 10-year and one-year Treasury constant maturity rates. The default spread $(D E F)$ is defined as the spread between the Moody's Baa corporate bond yield and the 10-year constant maturity Treasury bond yield. Fama and French (1993) identify that empirical proxies for the term and default factors explain a larger portion in the variation of government bond returns. Both the term spread and the default spread have been widely used in the empirical literature as proxies for the term and default factors and as indicators of general economic conditions (e.g. Jensen et al. 1996; Hahn and Lee 2003). The default spread is related to general credit conditions and is found to be high (low) when credit conditions are weak (strong). The term spread is more associated with monetary policy (Goodfriend 1998) and captures the near-term fluctuations in the business conditions, while the default spread also tracks the more persistent part of business conditions (Fama and French 1989).

For the regression model (Eq. 8), the author expected a positive sign on changes in term spread. Because the term spread tends to track loosening monetary policy and inflationary pressure, Treasury price will drop and yield will increase. On the other hand, the sign on default spread should be negative because more default risk will make investors seeking the safety of Treasury securities. As the national debt level may affect Treasury market behavior, the author included the natural log of all US government debt (PDEBT) as an additional control variable. The author also controlled for the specific amount of Treasury bills available at the next auction date (VISIBLE), which may influence the pricing of existing Treasury bills. The author expected that both PDEBT and VISIBLE will be positively associated with Treasury yields as the price of Treasury securities may encounter downward pressure when more the nation incurs more debt and when the Treasury department is auctioning off/providing more supply of Treasury bills. In addition, the number of days to maturity of the Treasury bill (DAYSMAT) is included as the slope of the yield curve may not be flat across different maturities of Treasury bills. ENDMO is a dummy variable that has the value of one if the maturity dates of two adjacent bills are split by the end of a calendar month. It is included because there might be a "kink" in the yield curve shape when the maturities of Treasury bills cross month end (see Park and Reinganum 1986). Table 1 reports summary statistics for the study.

Table 1

Summary Statistics

This table reports summary statistics for the study. Sample period includes the first trading day in June 2002 to the last trading day in May 2004. There are 10,648 observations of $\Delta Y_{i, t}$, defined as the daily yield change for Treasury bill $i$ on measurement

day $t$, annualized and expressed in basis points. $\triangle T E R M_{t}$ and $\triangle D E F_{t}$ are the daily change in the term spread (TERM, the spread between 10-year and one-year Treasury constant maturity rates. ) and default spread (DEF, the spread between Moody's Baa corporate bond yield and 10-year Treasury bond yield. $\triangle P D E B T$ is the natural log of total national debt and $\triangle$ Visible is the amount of upcoming Treasury bill auction.

\begin{tabular}{|l|c|c|c|c|c|}
\hline \multicolumn{1}{|c|}{ Variables } & Mean & Median & Std Dev & Min & Max \\
\hline$\Delta Y_{i, t}$ & -0.214 & -0.129 & 2.035 & -26.256 & 16.592 \\
\hline$\Delta T E R M_{t}$ & 0.035 & 0.000 & 4.692 & -21.000 & 17.000 \\
\hline$\Delta D E F_{t}$ & -0.182 & 0.000 & 3.098 & -14.000 & 14.000 \\
\hline$\triangle P D E B T$ & 0.000 & 0.000 & 0.002 & -0.004 & 0.018 \\
\hline$\triangle$ VISIBLE & 0.010 & 0.000 & 2.798 & -19.000 & 20.000 \\
\hline$D A Y S M A T$ & 109 & 107 & 48 & 1 & 190 \\
\hline ENDMO & 0.23 & 0.00 & 0.42 & 0.00 & 1.00 \\
\hline
\end{tabular}

\footnotetext{
${ }^{2}$ The author used SAS's PROC MIXED procedure, treating Treasury bills as subjects so that each bill is one cluster. The author applied the first-order auto-regressive covariance structure in the error terms of given bills across time. Each bill is identified by the CUSIP number. The goodness of fit for this procedure is given by the $-2 \log$ likelihood measure.
} 
Table 2 lists the ten event dates analyzed in this analysis. The event windows are based on the careful analysis by Auerbach and Hassett (2007) on the news events throughout the legislative process of JGTRRA. Table 3 reports that, among the ten events, Treasury bill yields first appear to increase when the dividend tax cut plan by the Bush Administration was first introduced in the House on February 27, 2003. The next statistically significant increase occurs on May 6, 2003, when the legislative proposal that set tax rates on dividends at 5 percent and 15 percent (5/15 plan) passed the House Ways and Means Committee.

Table 2

Key Event Dates for JGTRRA

\begin{tabular}{|l|l|l|l|}
\hline Event \# & \multicolumn{1}{|c|}{ Event Date } & \multicolumn{1}{|c|}{ Event Window } & \multicolumn{1}{c|}{ Description } \\
\hline 1 & $12 / 25 / 2002$ & $12 / 26 / 2002-12 / 30 / 2002$ & $\begin{array}{l}\text { The New York Times reports administration plans to reduce } \\
\text { dividend tax by 50\% }\end{array}$ \\
\hline 2 & $01 / 06 / 2003$ & $01 / 05 / 2003-01 / 07 / 2003$ & $\begin{array}{l}\text { The Wall Street Journal reports administration proposal to } \\
\text { eliminate the tax on dividends }\end{array}$ \\
\hline 3 & $02 / 27 / 2003$ & $02 / 26 / 2003-02 / 28 / 2003$ & Administration proposal introduced in House \\
\hline 4 & $03 / 04 / 2003$ & $03 / 03 / 2003-03 / 05 / 2003$ & House holds first hearing \\
\hline 5 & $03 / 27 / 2003$ & $03 / 26 / 2003-03 / 28 / 2003$ & $\begin{array}{l}\text { Thomas proposes } 8 / 18 \text { plan as alternative to elimination of } \\
\text { dividend tax }\end{array}$ \\
\hline 6 & $04 / 30 / 2003$ & $04 / 29 / 2003-05 / 01 / 2003$ & Thomas proposes 5/15 plan \\
\hline 7 & $05 / 06 / 2003$ & $05 / 05 / 2003-05 / 07 / 2003$ & House Ways \& Means passes 5/15 plan \\
\hline 8 & $05 / 09 / 2003$ & $05 / 08 / 2003-05 / 12 / 2003$ & House version of 5/15 plan passes \\
\hline 9 & $05 / 15 / 2003$ & $05 / 14 / 2003-05 / 16 / 2003$ & $\begin{array}{l}\text { Senate passes an alternative bill to the 5/15 plan that would have } \\
\text { set the dividend tax rate to zero, but only for one year before its } \\
\text { sunset }\end{array}$ \\
\hline 10 & $05 / 23 / 2003$ & $05 / 22 / 2003-05 / 27 / 2003$ & $\begin{array}{l}\text { Conference Committee version of JGTRRA passes House and } \\
\text { Senate }\end{array}$ \\
\hline
\end{tabular}

Table 3

Model of Treasury Bill Yield Change Around Key JGTRRA Event Dates

This table reports the results of ten regressions using the following regression model: $\Delta Y=\gamma_{0(n)}+\gamma_{(n)} D_{(n)}+k_{(n)}$ Control $+\varepsilon_{i, t(n)}$.

$\Delta Y$ is the daily yield change for Treasury bill $i$ on measurement day $t$, annualized and in basis points. $D_{(n)}$ is a dummy that is equal to one if measured on any day within the three-day event window $n$ and zero otherwise. Event windows are listed in Table 2. Estimation period starts from the first trading day in June 2002 and ends on the last trading day in May 2004. p-values in parentheses.

\begin{tabular}{|c|c|c|c|c|c|c|c|c|c|c|}
\hline 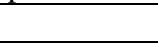 & \multicolumn{2}{|c|}{ Event 1} & \multicolumn{2}{|c|}{ Event 2} & \multicolumn{2}{|c|}{ Event 3} & \multicolumn{2}{|c|}{ Event 4} & \multicolumn{2}{|c|}{ Event 5} \\
\hline Start & \multicolumn{2}{|c|}{$12 / 25 / 2002$} & \multicolumn{2}{|c|}{$1 / 05 / 2003$} & \multicolumn{2}{|c|}{$2 / 26 / 2003$} & \multicolumn{2}{|c|}{$3 / 03 / 2003$} & \multicolumn{2}{|c|}{$3 / 26 / 2003$} \\
\hline End & \multicolumn{2}{|c|}{$12 / 30 / 2002$} & \multicolumn{2}{|c|}{$1 / 07 / 2003$} & \multicolumn{2}{|c|}{$2 / 28 / 2003$} & \multicolumn{2}{|c|}{$3 / 05 / 2003$} & \multicolumn{2}{|c|}{$3 / 28 / 2003$} \\
\hline & & t-stat & & t-stat & & t-stat & & t-stat & & t-stat \\
\hline Intercept & -0.185 & -3.62 & -0.186 & -3.64 & -0.191 & -3.73 & -0.185 & -3.61 & -0.181 & -3.55 \\
\hline$D_{(n)}$ & -0.217 & -0.83 & 0.023 & 0.07 & 0.677 & 2.74 & -0.121 & -0.50 & -0.889 & -3.47 \\
\hline$\Delta T E R M_{t}$ & 0.013 & 2.72 & 0.013 & 2.74 & 0.013 & 2.8 & 0.013 & 2.73 & 0.013 & 2.72 \\
\hline$\Delta D E F_{t}$ & -0.187 & -26.5 & -0.187 & -26.52 & -0.187 & -26.56 & -0.187 & -26.51 & -0.187 & -26.60 \\
\hline$\triangle P D E B T$ & 36.10 & 3.26 & 36.28 & 3.27 & 36.76 & 3.32 & 36.40 & 3.29 & 35.86 & 3.24 \\
\hline$\triangle V I S I B L E$ & 0.014 & 1.99 & 0.014 & 2 & 0.014 & 2.05 & 0.014 & 2.00 & 0.013 & 1.97 \\
\hline DAYSMAT & -0.001 & -1.67 & -0.001 & -1.68 & -0.001 & -1.68 & -0.001 & -1.68 & -0.001 & -1.67 \\
\hline ENDMO & 0.015 & 0.32 & 0.015 & 0.31 & 0.015 & 0.32 & 0.015 & 0.31 & 0.015 & 0.32 \\
\hline $\begin{array}{l}-2 \text { log- } \\
\text { likelihood }\end{array}$ & $-44,291$ & & $-44,292$ & & $-44,284$ & & $-44,292$ & & $-44,280$ & \\
\hline
\end{tabular}


Table 3 (Continued)

Model of Treasury Bill Yield Change Around Key JGTRRA Event Dates

\begin{tabular}{|c|c|c|c|c|c|c|c|c|c|c|}
\hline & & & & & & & & & & \\
\hline & & & & & & & & & Eve & 10 \\
\hline Start & $4 / 2$ & 003 & $5 / 0$ & 003 & $5 / 08$ & 003 & $5 / 1$ & 003 & $5 / 2$ & 003 \\
\hline End & $5 / 0$ & 003 & $5 / 0^{\prime}$ & 003 & $5 / 12$ & 003 & $5 / 1$ & 003 & $5 / 2$ & 003 \\
\hline & & t-stat & & t-stat & & t-stat & & t-stat & & t-stat \\
\hline Intercept & -0.178 & -3.5 & -0.190 & -3.71 & -0.185 & -3.61 & -0.179 & -3.52 & -0.191 & -3.74 \\
\hline$D_{(n)}$ & -1.279 & -5.04 & 0.702 & 2.77 & -0.115 & -0.47 & -1.121 & -4.45 & 1.008 & 3.88 \\
\hline$\Delta T E R M_{t}$ & 0.013 & 2.84 & 0.014 & 2.94 & 0.013 & 2.73 & 0.012 & 2.51 & 0.013 & 2.76 \\
\hline$\Delta D E F_{t}$ & -0.187 & -26.54 & -0.187 & -26.56 & -0.187 & -26.51 & -0.187 & -26.62 & -0.186 & -26.44 \\
\hline$\triangle P D E B T$ & 35.42 & 3.2 & 36.50 & 3.3 & 36.20 & 3.27 & 35.95 & 3.25 & -0.001 & -1.65 \\
\hline$\triangle V I S I B L E$ & 0.013 & 1.94 & 0.014 & 2 & 0.014 & 1.99 & 0.014 & 1.98 & 0.015 & 0.32 \\
\hline DAYSMAT & -0.001 & -1.67 & -0.001 & -1.67 & -0.001 & -1.68 & -0.001 & -1.68 & 29.65 & 2.65 \\
\hline ENDMO & 0.015 & 0.31 & 0.015 & 0.31 & 0.015 & 0.31 & 0.015 & 0.32 & 0.017 & 2.48 \\
\hline $\begin{array}{l}-2 \text { log- } \\
\text { likelihood }\end{array}$ & $-44,266$ & & $-44,284$ & & $-44,291$ & & $-44,272$ & & $-44,277$ & \\
\hline
\end{tabular}

Among the ten event windows, three are associated with declines in the Treasury bill yields. The first decline is on March 27 when William Thomas, Chair of the House and Ways and Means Committee, proposed an alternative plan that would replace the initial Bush plan to eliminate the dividend tax with reduced tax rates on dividends and capital gains at 8 percent or 18 percent (8/18 plan). The second decrease took place on April 30 when Mr. Thomas announced a modified version of his $8 / 18$ plan that would reduce the rates on dividends and capital gains to 5 percent and 15 percent. There is a third decline on May 15 when the Senate passed still another alternative plan that would eliminate the dividend tax, but only for one year before its sunset. These declines all seem to relate to Congressional actions attempting to modify the initial Bush tax plan and might have suggested to the market that the Bush tax cut plan had encountered resistance in the legislative process (Auerbach and Hassett 2007).

The final event is associated with an increase in the Treasury bill yields, as the Conference Committee version of the JGTRRA passed the House and Senate, with Vice President Cheney casting the tie-breaking vote in the Senate. Although not large, the average change in Treasury bill yields is estimated to be 1.13 basis points within the event window surrounding May 23, 2003 when JGTRRA finally passed the House and Senate. This is consistent with arbitrage-related activities by tax-exempt investors such as pension funds (see Guenther 1994). It should also be noted that there might be a supply-side reaction of investors to sell stocks following a cut in the capital gains rate by JGTRRA referred to as the "lock-in" effect. Both the lock-in and the activities by tax-exempt investors would bias against finding a positive yield change on the Treasury market as investors rebalance their portfolios into the stock market.

\section{CONCLUSIONS}

The yields from U.S. Treasury bills are treated as ordinary income to individual investors (Internal Revenue Code Section 1271(a)(3)(A)). The passage of JGTRRA in 2003 started a new decade in which ordinary income are taxed at a substantial higher rate than dividends and capital gains. Miller (1977) predicts that “...If, therefore, the personal tax on income from common stocks is less than that on income from bonds, then the before-tax return on taxable bonds has to be high enough, other things equal, to offset this tax-handicap." The author adopted an event study approach to test changes in Treasury bill yields surrounding key events in the legislative process of JGTRRA. There appears to be positive and statistically significant yield changes when JGTRRA was first introduced in the House, when the House Ways and Means passed the 5/15 plan and when JGTRRA finally passed the House and Senate. The result suggests that a tax policy intentionally favoring dividends and capital gains over ordinary income may unintentionally push up yields in the Treasury bill market, thereby affecting the cost of government borrowing. 


\section{AUTHOR INFORMATION}

Mingjun Zhou is an Assistant Professor in the School of Accountancy and Management Information Systems at DePaul University. He earned his Ph.D. from Texas Tech University. His research interests focus on the impact of information systems and executives on firm financial measures. His articles appeared in Accounting and Taxation and Journal of Accounting, Ethics and Public Policy, and the Review of Business Information Systems. E-mail: mzhou4@depaul.edu

\section{DATA AVAILABILITY}

The data are available from public sources identified in this study.

\section{REFERENCES}

1. Auerbach, A.J., and K. Hassett. 2007. The 2003 dividend tax cuts and the value of the firm. In Taxing Corporate Income in the $21^{\text {st }}$ Century, edited by A.J. Auerbach, J. R. Hines, Jr., and J. Slemrod. 93-126. Cambridge, NY: Cambridge University Press.

2. Campbell, J., and R. Shiller. 1991. Yield spreads and interest rate movements: A bird's eye view, The Review of Economic Studies 58, 495-514.

3. Dai, Z., E. Maydew, D. Shackelford and H. Zhang. 2008. Capital Gain Taxes and Assest Prices: Capitalization or Lock-in? Journal of Finance 63-2, 709-742

4. Dhaliwal, D., L. Krull and O. Z. Li. 2007. Did the 2003 tax act reduce the cost of equity capital? Journal of Accounting and Economics 43, 121-150

5. Lightner, T., R. Ricketts, M. Riley and M. Morrow. 2008. Investor response to a reduction in the dividend tax rate: evidence from the Jobs \& Growth Tax Relief Reconciliation Act of 2003. Journal of the American Taxation Association 30(2), 21-46.

6. Fama, E., and K. French. 1989. Business conditions and expected returns on stocks and bonds, Journal of Financial Economics 25, 23-49.

7. Fama, E., and K. French. 1993. Common risk factors in the returns on stocks and bonds, Journal of Financial Economics 33(1), 3-56.

8. Goodfriend, M. 1998. Using the term structure of interest rates for monetary policy, Federal Reserve Bank of Richmond Economic Quarterly 84(3), 13-30.

9. Guenther, D. 1994. The relation between tax rates and pre-tax returns: Direct evidence from the 1981 and 1986 tax rate reductions. Journal of Accounting and Economics 18 (3), 379-393.

10. Hahn, J., and H. Lee. 2006. Yield spreads as alternative risk factors for size and book-to-market, Journal of Financial and Quantitative Analysis 41(2), 245-269.

11. Jensen, G., J. Mercer and R. Johnson. 1996. Business conditions, monetary policy, and expected security returns. Journal of Financial Economics 40, 213-217.

12. Lang, M., and D. Shackleford. 2000. Capitalization of capital gains taxes: Evidence from stock price reactions to the 1997 rate reduction. Journal of Public Economics 76 (1): 69-85.

13. Mankiw, N.G., and J. M. Poterba. 1996. Stock market yields and the pricing of municipal bonds. National Bureau of Economic Research Working Paper No.5607. Cambridge, MA: NBER.

14. $\quad$ Miller, M. 1977. Debt and Taxes, Journal of Finance 32 (2): 261-275.

15. Miller, M., and F. Modigliani. Dividend policy, growth, and the valuation of shares. Journal of Business 34 (1961): 411-433

16. Novack, G. 2005. Treasury bill yield reactions to the 1997 capital gains tax reduction. Journal of the American Taxation Association (27) Supplement, 55-70.

17. Park, S. and M. Reinganum, 1986. The puzzling price behavior of treasury bills that mature at the turn of calendar months. 16 (2)

18. Petersen, M. 2009. Estimating standard error in finance panel data sets: Comparing approaches, Review of Financial Studies 22: 435-480.

19. Roll, R. 1970. The behavior of interest rates: An application of the efficient market model to U.S. Treasury bills (Basic Books, Inc. New York, NY.).

20. Stock, J., and M. Watson.1999. Forecasting inflation, Journal of Monetary Economics 44(2), 293-335. 


\section{NOTES}

